\title{
Politik Taktikler: İçsel Motivasyonun Bir Yansıması mı? Yöneticiler Perspektifinden Havacılık Sektöründe Bir Araştırma
}

\author{
DOI: $10.26466 / o p u s .585532$
}

*

\author{
$\underline{\text { Taha Yusuf CCakarel }}^{*}$ - Deniz Elber-Börü** - Bekir Alper Yıldırım*** \\ * Arş.Gör. İstanbul Kültür Üniversitesi, İ.İ.B.F., Bakırköy / İstanbul / Türkiye \\ E-Posta: t.cakarel@iku.edu.tr \\ ORCID: $\underline{0000-0002-8238-4911}$ \\ ** Prof. Dr., Marmara Üniversitesi, İşletme Fakültesi, Kadıköy / İstanbul / Türkiye \\ E-Posta: denizboru@marmara.edu.tr ORCID: 0000- 0002-3916-9765 \\ *** Doktora Öğrencisi Marmara Üniversitesi, S.B.E., Kadıköy / İstanbul / Türkiye \\ E-Posta: bekiralperyildirim@gmail.com \\ ORCID: 0000-0001-5107-0242
}

\section{Öz}

Bu çalışmada yöneticilerin içsel motivasyon düzeylerinin politik taktikler üzerine olan etkisive bu iki kavramın birbiri ile olan ilişkisi incelenmiş olup, yöneticilerin içsel motivasyon düzeyleri ile politik taktiklere başvurma dereceleri arasındaki ilişki ortaya konmak istenmektedir. İçsel motivasyon ve politik taktikler üzerine daha önce gerçekleştirilmiş olan akademik çalışmalar genellikle çalışanlar üzerine ve nicel yöntemler kullanarak gerçekleştirilmiş olup bu çalışmada ise havacıllk sektöründe faaliyet gösteren $n=16$ yönetici üzerinde yarı yapılandırılmış mülakat formları ile ve nitel yöntemle derinlemesine analiz yöntemi kullanılmıştır. Mülakat formlarındaki sorular nicel yöntemlerden esinlenerek oluşturulmuştur. Çalışmada yöneticilerin içsel motivasyon düzeyleri belirlenmeye çalışılmış ve politlik taktiklere başvurma düzeyleri ile ilişkilendirilerek bir anlam matrisi oluşturulmaya çalışılmıştır. Çalışma sonunda yöneticilerin içsel motivasyon düzeyleri ile politik taktikleri kullanım sıklıkları arasında belirgin bir ilişki tespit edilmiş ve bu tespitler doğrultusunda analizler ve öneriler yapılmıştır. Buna karşın yumuşak (göze girme, mantıkla ikna etme) ve sert politik taktiklerin motivasyon düzeyleri arasındaki dağılım incelendiğinde ise mantıklı ve tutarlı bir dă̆glım görülememiştir.

Anahtar Kelimeler: İçsel motivasyon, Politik taktikler, İş motivasyonu, Politik davranış 


\title{
Political Tactics: A Reflection of Intrinsic Motivation? A Research in The Aviation Industry From Managers Perspective
}

\begin{abstract}
In this study, the effect of managers intrinsic motivation levels on political tactics and the relationship between these two concepts are examined and it is aimed to reveal the relationship between managers intrinsic motivation levels and the degree of applying to political tactics. Previous academic studies on intrinsic motivation and political tactics were generally conducted on employees and by using quantitative methods, and this study, $n=16$ managers working in the aviation industry used semi-structured interview forms and in-depth analysis with qualitative method. This questions in the interview forms were inspired by quantitative methods. In this study, the level of intrinsic motivation of the managers was tried to be determined and a meaning matrix was tried to be formed in relation to the levels of applying politic tactics. At the end of the study, managers intrinsic motivation levels and frequency of using political tactics a significant relationship has been identified and analyzes and suggestions have been made in line with this findings. On the other hand, when the distrubition between the motivation levels of soft tactics was not examined, a logical and consistent distribution could not be seen.
\end{abstract}

Keywords: Intrinsic motivation, Political tactics, Work motivation, Political behavior 


\section{Giriş}

Örgütler belirlenmiş amaç veya amaçları gerçekleştirmek üzere faaliyet gösteren yapılardır. Belirlenen amaçlara ulaşmak için gerekli olan kaynakları sağlayan örgüt, bu kısıtlı kaynakları etkili ve verimli bir şekilde kullanmak için minimum girdi ile maksimum fayda elde etmek isteyecektir. Bunu gerçekleştirmek isteyen örgütler için en önemli kaynak insan ve bu insanın istekliliğidir. Yapılan çalışmalarda, insanı istekli kılan, insanı harekete geçiren etkinin kaynağında içsel ve dişsal olarak tanımlanan motivasyonun var olduğu belirtilmektedir. Buna göre insan kendi güdülerine dayalı olarak ya da dışarıdan gelen veya gelecek olan teşvikler ile harekete geçebilir. Örgüt yapısı ve yöneticiler, bireylerin motivasyonunu sağlamada en önemli faktörler olarak belirtilmiştir. (Özdaşlı ve Akman, 2012). Diğer yandan amaçlara ulaşma yönünde istekli davranan, motive olmuş bireyler, bu isteklerini gerçekleştirmek üzere örgütsel kaynakları kullanma doğrultusunda girişimlere yöneleceklerdir. Örgütlerin kaynaklarının kısıtlı olması ve kaynak paylaşımında örgüt içerisinde bireylerin birbirlerine rakip olması yine örgüt içerisinde politik davranışların oluşmasına ve bireylerin birbirlerine karşı politik taktikler kullanmasına yol açmaktadır (Robbins, 2001). Özellikle yönetsel başarılarını ortaya koymak adına, yönetim kademesindekilerin bu davranışları çalışanlara oranla daha çok ortaya koyacakları ön görülmektedir. Buradan yola çıkarak bu çalışmada, yöneticilerin içsel motivasyonları ile politik taktikleri kullanmaları arasındaki ilişki ortaya konmak istenmektedir. Literatür incelendiğinde, içsel motivasyon ve politik taktik kullanımı üzerine yapılan çalışmaların ağırlıklı olarak nicel araştırmalar olduğu ve çalışanlar üzerinde yapıldığı görülmektedir (Türk vd., 2003; Armağan, 2005; Öğüt vd., 2004; Ergül, 2005; Arıkan, 2011; Mohan, 2008; Çalışkan, 2006; Ülkeryıldız, 2009; Lipset, 1959; Boddevyn vd., 1994; Zuckerman, 2005). Bu çalışmada ise, nitel araştırma yöntemi kullanılmış ve orta kademe yöneticiler üzerinde inceleme gerçekleştirilmiştir. Bu yönüyle çalışma özgün bir nitelik taşımaktadır. Çalışmanın örneklemi havacılık sektöründen belirlenmiştir. 


\section{Kavramsal Çerçeve}

İş yerinde politik taktik kullanımı ve motivasyon kavramları, örgüt psikolojisinin ve dolayısıyla örgütsel davranış konularının çalışma alanına girmektedir. Sosyal psikoloji alanında özellikle 1950'li yıllardan sonra çok sayıda bilimsel araştırma yapılmış ve yapılmaya devam ediyor olması ve bireylerin toplum içerisindeki davranışlarını büyük ölçüde açıklıyor oluşu, örgüt psikolojisi kavramının ilerlemesini hızlandırmıştır (Veysel vd., 2008).

\section{İçsel Motivasyon}

İnsan davranışlarının temelinde ihtiyaçlar yer almaktadır. İnsanlar amaçlarına hizmet edecek çabaları gösterme eğilimindedirler (Özadaşlı ve Akman, 2012). Bu da insanların çabalarının başkalarından önce kendi ihtiyaçlarını giderme yönünde olduğunu gösterir. Bu bağlamda içsel motivasyon kısaca, bireylerin kendi yeteneklerini ortaya koyma deneyimi olarak tanımlanabilir (Brief ve Aldag, 1977). İçsel motivasyonun araçları doğrudan işin doğasıyla ilgili olup aynı zamanda işin içeriğinden de kaynaklanmaktadır. İçsel motivasyonun araçları, ilgi çeken ve zorlayıcı işler, iş yerinde ve işte bağımsızlık, çalışan açısından işin önemi, işe katılım, çeşitlilik, sorumluluk, yetkinlik, yaratıcılık, performans ile ilgili tatmin edici geri bildirimler, bireyin becerilerini ve yeteneklerini kullanabilme firsatı şeklinde tanımlanabilir (Mottaz, 1985). Bu araçlar, bireyleri bir şeyler yapmak için harekete geçirir ve dolayısıyla motive olmalarını sağlamaktadır (Ryan ve Deci, 2000).

İçsel motivasyon, iş yapılırken, gerçekleştirilen işin dışında herhangi bir görünen ödülle motivasyon sağlanmadığı durumlarda söz konusu olmaktadır. Dışsal motivasyon araçları süreli bir motivasyonu mümkün k1larken, içsel motivasyonu sağlayacak uygulamalar daha uzun süreli etki yaratmaktadır. Çalışanların sosyal ortamlarının yeterli olması, yönetime katılım imkanlarının artırılması ve kurum içi ilişkilere yönelik olumlu hisleri; bireyin içsel motivasyonunu sürdürmesini ve dışsal motive edici unsurlara kıyasla hayatında daha çok kendisinin belirleyici konumda olduğunu hissetmesini sağlayabilmektedir (Batmaz ve Gürer, 2016). 
İçsel motivasyon, bireylerin bir faaliyeti gerçekleştirirken yaptıkları işin dışında görünen herhangi bir ödül ile elde edilmesiyle de söz konusu olmaktadır (Deci, 1972). Bundan dolayı içsel motivasyonda iş ile ödül arasinda hızlı ve doğrudan bir bağlantı vardır (Newstrom ve Davis, 2002). Bunlara rağmen bireylerin sadece ihtiyaçlardan doğan motivler ile harekete geçeceklerini söylemek doğru değildir. İhtiyaçların giderilmesi, arzu ve isteklerin yerine getirilmesinin dışında değerler için de çaba sarf edileceğini belirtmek mümkündür. Bu bağlamda insanların efsaneler, namus, fikir, bayrak, idol, rozet ve benzeri şeyler için de çaba sarf ettikleri ve hatta bu değerler adına çok daha fazlasını yapabildikleri görülmektedir. Bütün bunların ışığında içsel motivasyon, bireylerin belirli amaçları gerçekleştirme veya benimsedikleri değerleri uğruna kendi arzu ve istekleri ile çaba göstermeleri şeklinde tanımlanabilmektedir (Koçel, 2007).

İçsel motivasyonu olan bireyler yeni bir şeyler öğrenmek veya keşfetmek, kapasitelerini arttırmak için içsel bir eğilime sahiptirler. Bir dışsal ödül olmaksızın yalnızca öğrenme istekleri ve meraklarından kaynaklanan bir motivasyona sahip olan bu bireylerde yaratıcılık beklenen bir özelliktir(Gürkan ve Demiralay, 2017). Woodworth (1918)'a göre, bir faaliyet dışsal etkiler veya motivler ile başlayabilir fakat, birey içsel olarak arzulu olursa etkili ve özgür bir şekilde faaliyetlerine devam edebilir. Bu anlamda içsel motivasyonu yüksek bireylerin, işin sürdürülmesinde önemli bir rolleri vardır. Bu bireylerin başarıya ulaşma konusunda duydukları istek, başarıya ulaşma yolunda farklı yolları denemelerine ve farklı araçları kullanmalarına da yol açmaktadır.

Bireylerin eylemlerini daha iyi anlayabilmek için her motivasyon türü değişik araştırmalarla incelenmektedir. Çoğu araştırma sonucu içsel motivasyonun en etkili tür olduğunu ortaya koymuştur. Bireyler içsel olarak güdülendiklerinde görevlerini içlerinden gelerek ve itinayla yerine getirirler. Bu doğrultuda içsel motivasyon, bireyin yeterlilik ve becerilerini gösterme tecrübesidir (Yilmaz, 2018).

\section{Politik Taktikler}

Örgüt içerisinde kaynakların kısıtlı olması ve bu kaynakların paylaşımında bireylerin birbirlerine rakip olması sebebiyle örgüt içerisinde poli- 
tik davranışların görülmesi ve bireylerin birbirleri karşısında politik taktikler kullanması kaçınılmazdır (Robbins, 2001). Politik davranış konu edilmiş olan birçok araştırmada davranışın stratejik bir şekilde kullanılması yolu ile kısa ve uzun vadede uygulayıcıya çıkar sağlamayı hedefleyen kasıtlı davranışlar ve etkileme taktikleri olarak tanımlanmaktadır (İslamoğlu ve Börü, 2007).

Bir çok araştırmacı politik taktiklerin kullanımını kişisel çıkarlar ile ilişkilendirmiş ve bu çerçevede sınırlandırmıştır (İslamoğlu ve Börü, 2007; Drory ve Vigoda-Gadot, 2010; Dulebohn vd., 2005; Hochwarter vd., 2000; Parker, 1995). Buna karşın çalışanların örgütsel ortamlarını politik olduğunu algılamaları beraberinde bir takım sonuçları da getirmektedir. Örneğin örgütte terfi bekleyen ve bunu hak ettiği düşünen bir çalışan, hak etmediğini düşündüğü başka bir çalışanın terfi aldığını gördüğünde, yönetici ve/veya örgütün bir takım politik kararlar aldığını düşünecektir. Bu durum bireyin, işinde mutlu olması ve yüksek performans sergilemesinin kaynağı olan adalet ile güven algılarını sarsabilecektir. Tam aksine amiri tarafından terfi ettirilen kişi için olumsuz değerlendirmelere yol açmayacak, bu yönde davranışı takdir bulacaktır. Bu çerçeveden değerlendirildiğinde, bireylerin çalışma ortamları hakkında politik algılarının şekillenme biçimi, bireyin örgüt içerisinde davranışlarını ve dolayısıyla çalışma yaşamını şekillendirebilmektedir (Eryılmaz ve Gülova, 2017)

Politik davranış ve taktiklerin kuruma fayda veya zarar getirmesi daha çok bireylerin kullanım amacına bağlıdır (Drory ve Vigoda-Gadot, 2010). Örgütteki ortamın bireyler tarafından politik bir biçimde algilanması, bireylerin gözünde politik faaliyetlerin meşrulaşmasını ve politik davranışları sergilemenin daha kabul edilir bir hal almasını sağlayabilecektir. Böylece politik davranma olasılığı ve bunu yapanların sayısı artabilecektir. Bunun da ötesinde bireylerin politik algılamaları, politik davranışları uygularken kullanacakları taktiklerin belirlenmesinde de etkili olabilecektir (Bağcı ve Bursalı, 2011).

Kişiler arası etkileşim çalışmalarının yoğunlaşması ile birlikte politik taktiklere yönelik gerçekleştirilen tanım ve sınıflandırmalar netleşmiştir (Bruins, 1999; Steensma, 2007). Politik amaçlı etkileme taktiklerinin ölçümü Kipnis, Schmidt ve Wilkinson (1980)'un gerçekleştirdiği sınıflama ile gelişme kaydetmiştir. Steensma (2007)'de Kipnis ve arkadaşlarının gerçekleştirdiği çalışmayı geliştirerek politik taktikleri 6 temel taktik üzerine 
sinıflandırmıştır. Bu taktikler göze girme, destek oluşturma, üst makama başvurma, mübadele, kendini fark ettirme ve mantıkla ikna etme olarak tanımlanmıştır (Steensma, 2007). Bunlardan göze girme ve mantıkla ikna etme yumuşak taktikler, diğerleri ise sert taktikler olarak da sınıflandırılabilir.

Göze girme, kendini hedef kişiye daha da çekici göstermeye yönelik davranışlardır (Liden ve Mitchell, 1988). Bu taktiği kullanan bireylerin hedef kişiler ile olumlu olan ortak noktalarını ön plana çıkarma eğiliminde oldukları belirtilmiştir (Judge ve Bretz Jr., 1994; Liden ve Mitchell, 1988). Bu taktiği uygulayan birey istediğini yaptırabilmek için hedef bireyin keyifli anını kollar ve bu birey hakkında övgülerde bulunarak, hedef bireyin kendisini önemli hissetmesini sağlar. Bu sayede bir istekte bulunacağı zaman dost ve olumlu görünme eğiliminde olur (Appelbaum ve Hughes, 1998; Dulebohn vd., 2005; İslamoğlu ve Börü, 2007; Elias vd., 2004; Pandey, 1981; Shankar, 1994; Yukl ve Tracey, 1992).

Destek oluşturma, birey isteğini gerçekleştirmek için çevresinde bulunan diğer bireylerin desteğinden faydalanması ve bu diğer bireyler ile koalisyon kurarak öneri ve isteklerinin dikkate alınmasını sağlar (İslamoğlu ve Börü, 2007; Yaylacı, 2006).

Üst makama başvurma, hedeflenen bireyi etkileyebilmek adına örgütte daha üst makamlarda bulunan bağlantılarını devreye sokarak hedef bireyin isteklerini gerçekleştirmesini sağlamasıdır (İslamoğlu ve Börü, 2007; Yaylac1, 2006; Elias vd., 2004).

Mübadele, birey açık veya örtülü bir biçimde hedef kişiye isteğini gerçekleştirmesi durumunda ödüllendirme yapacağını belirten bir mesaj gönderir. Bu ödül genellikle hedef bireyin bir isteğinin gerçekleştirilecek olmasıdır. Bunun dışında hedef kişiye daha önce yapılmış olan bir iyiliğin hatırlatılması ile de gerçekleştirilebilir (Ceylan, 2004; Elias vd., 2004).

Kendini fark ettirme, bireyin kendi isteklerinin gerçekleştirilmesi uğruna iş konularında olduğundan daha yetkin ve bilgili görünmeye çalışmasını ifade eder (Judge ve Bretz Jr., 2004). Bireyler yetkinlikleri ile birlikte bilgi 
ve becerilerini de abartabilirler. Başarısızlıklarını gizleme eğilimi gösterirken başarılarını ise üst makamlara duyurabilmek için her türlü çabayı gösterme eğilimindedirler (Orpen, 1996; Dulebohn vd., 2005).

Mantıkla ikna etme, hedef bireye istediğini yaptırabilme uğruna mantıklı deliller ile ikna etme çabası içerisinde olma durumunu ifade etmektedir (Yukl ve Falbe, 1990; Elias vd., 2004).

\section{İçsel Motivasyon ve Politik Taktikler}

Literatürde çalışanların iş ortamında politik taktikleri kullanmaları temelde iki faktör altında toplanmaktadır: a)bireysel etkileşiminden kaynaklanan nedenler b)örgütsel ve iş çevre etkileşiminden kaynaklanan nedenler (Arıkan, 2011)

Politik taktiklerin bireysel etkileşiminden kaynaklanan nedenleri üzerindeki çalışmalar incelediğinde çalışanların kişilik özelliklerinin, güdülerinin, ihtiyaçlarının, cinsiyetlerinin, çalıştıkları şirkete yapmış oldukları yatırımların ve kariyer hedeflerinin önemli değişkenler olarak ortaya çıtığını görülmektedir (İslamoğlu ve Börü, 2007; Robbins, 2001; Arıakn, 2011). Bireyin güç, güvenlik, statü gibi ihtiyaçları, başarıya ulaşma konusunda duyduğu arzu onun politikleşmesine, politik taktikler kullanmasına zemin hazırlayan güçlü güdüleme kaynakları olarak değerlendirilmektedir. Treadway ve arkadaşları (2005) yaptıkları çalışmada yüksek başarı ihtiyacı olan ve iç motivasyonu yüksek olan kişilerde politik taktiklerin ve politik davranışın daha fazla olacağını kanıtlamıştır. İçsel motivasyon, fırsatları yakalama, yetkinliği gösterme ve çıkarlarını gözetme gibi amaçlara hizmet ettiğinden hedefe yönelik davranış olarak tanımlanabilir. Öz benlik yönelimi teorisi, içsel motivasyonun hedefleri gerçekleştirme doğrultusundaki çabalarının bireyin psikolojik ihtiyaçlarının karşılanması, sağlık ve güvenliğinin sağlanması açısından etkili olduğunu savunmaktadır. Bu bağlamda içsel motivasyonu yüksek olan bireyler hedefe ulaşmada, politik taktik kullanımı ya da politik davranışa yönelim gibi, öz benlik yönelimli davranışlar ortaya koyabilmektedirler. Ancak başarı beklentisi yüksek bireyler eğer uygulayacakları politik taktik ve sergileyecek- 
leri politik davranışların örgütteki başarılarını engelleyeceklerini düşünüyorlarsa daha az politik davranma eğiliminde olacaklardır (Robbins ve Judge, 2013; Oruç ve Kutaniş, 2015).

Yapısal özellikleri temelinde, kendi gücünü davranışlarıyla ortaya koyarak davranışsal tepkilerini oluşturmak isteyen bireyler, olaylara karşı proaktif tepkiler verme eğiliminde olup, durumları kendi lehlerine yönlendirmeye çalışmaktadırlar. Dolayısıyla çevreyi kontrol edebileceklerine inandıklarından yüksek düzeyde sosyal uyum davranışı göstererek politik davranışa yönelebilmektedirler. Bu konuda Ralston (1985) bireylerin göze girmeye çalışma taktiklerini kullanmalarının daha olası olduğunu belirtmiştir.

\section{Metodoloji}

$\mathrm{Bu}$ araştırmanın temel amacl; yöneticilerin içsel motivasyon düzeyleri ile işyerinde kullandıkları politik taktikleri incelemek ve içsel motivasyon düzeyleri ile politik taktiklere başvurma sıklıkları arasındaki ilişkiyi ortaya koymaktır. Bu bağlamda çalışmanın araştırma sorunsalları "acaba yöneticiler arasında içsel motivasyon düzeyleri açısından politik taktik kullanımı farklılaşmakta mıdır?", "yöneticiler içsel motivasyon düzeyleri düş̧ükçe, daha mı çok politik taktik kullanılmaktadır?", "sert ve yumuşak politik taktikler hangi içsel motivasyon düzeyinde daha belirgin olarak kullanılmaktadır?" şeklinde belirlenmiştir.

Literatürdeki diğer içsel motivasyon ve politik taktikler konularındaki araştırmaları incelendiğinde, çalışmaların genellikle çalışanlar üzerinde ve nicel yöntem benimsenerek yapıldığı görülmektedir (Dündar,Özutku ve Taşpınar, 2007; Özdaşlı ve Akman,2012; Arıkan, 2011). Bu çalışma da ise fenomenolojik bir metod kullanılarak herkesin bildiği fakat derinden ilişki kuramadığı kavramlar üzerinden tanım ve içerik analizleri yapılmıştır. Çalışmanın yöneticiler üzerine olması ve araştırma örnekleminin sayıca kısıtlı olması nedeniyle de nitel araştırma yöntemine başvurulmuştur.

Çalışmada içsel motivasyonla ilgili sorular Amabile (1994)'nin oluşturduğu ve Dündar (2007)'ın geliştirdiği içsel motivasyon ölçeğinden uyar- 
lanarak hazırlanmıştır. Politik taktikler ölçeği ise; Kipnis, Schmidt ve Wilkinson (1980)'un oluşturduğu ve Steensma (2007)'nın geliştirdiği Sert ve Yumuşak politik taktikler ölçeğinden uyarlanarak hazırlanmıştır.

Araştırmanın örneklemi, 2018 yılında Türkiye'de yurtiçi ve yurtdışında faaliyet gösteren bir havayolu işletmesindeki $n=16$ yönetici olarak belirlenmiştir. Katılımcıların tamamı erkek olup, demografik özellikleri aşağıda Tablo 1'de sunulmaktadır.

Tablo 1. Yöneticilere İlişkin Demografik Özellikler

\begin{tabular}{ll}
\hline Yaş & \\
\hline $30-40$ yaş & $\mathrm{n}=6(\% 3)$ \\
\hline $40-60$ yaş & $\mathrm{n}=10(\% 63)$ \\
\hline Çalışma Kıdemi & \\
\hline 6-10 yıl & $\mathrm{n}=4(\% 25)$ \\
\hline $10-20$ yıl & $\mathrm{n}=8(\% 50)$ \\
\hline $21-+$ yıl & $\mathrm{n}=4(\% 25)$ \\
\hline Eğitim Düzeyi & \\
\hline Lisans & $\mathrm{n}=12(\% 75)$ \\
\hline Yüksek Lisans & $\mathrm{n}=4(\% 25)$ \\
\hline Görev & \\
\hline Müdür & $\mathrm{n}=10(\% 63)$ \\
\hline Şef & $\mathrm{n}=6(\% 37)$ \\
\hline
\end{tabular}

Çalışmada araştırmacılar tarafından hazırlanan yarı yapılandırılmış mülakat formları ile yöneticilerle görüşmeler yapılmıştır. Mülakatlar iki basamakta yapılandırılmıştır. İlk basamakta bir araştırmacı içsel motivasyon konusu ile ilgili yarı yapılandırılmış mülakat sorularını yöneticilere yöneltmiştir. Ardından bir hafta sonra mülakatın ikinci aşamasına geçilmiş ve bir başka araştırmacı yöneticilere politik taktikler konusunda hazırlanmış yarı yapılandırılmış mülakat sorularını yöneltmiştir. Böylelikle zamanı etkin kullanmak, yöneticileri üst üste konularla sıkmamak ve yönlendirmemek, ayrıca çalışmada objektiviteyi sağlamak hedeflenmiştir.

Her bir mülakat yaklaşık 30 dakika ile sınırlandırılmıştır. Mülakatlar, önceden randevu alınarak belirlenmiş tarih ve zamanda iş yerlerinde kişiler ziyaret edilerek yapılmıştır. Yöneticilere içsel motivasyon düzeylerini belirleme yönünde basitten zor ve karmaşıklığa doğru sıralanmış 10 adet yarı yapılandırılmış soru yöneltilmiş ve karşılıklı soru cevap tekniği 
ile görüşme notları tutulmuştur. Politik taktikler ile ilgili olarak ise 6 temel politik taktik öğesinin her biri için 2'şer adet açık uçlu, kavrama yönelik yarı yapılandırılmış soru formu katılımcilara verilmiş, bu taktikleri "uyguladıkları" veya "uygulamak istedikleri" şeklinde cevaplandırmaları istenmiştir. Ayrıca yarı yapılandırılmış soru formunun doldurulması sırasında araştırmacıların derinlemesine analiz yapmasına olanak sağlayan yazılı notlar da tutulmuş ve analizlerde dikkate alınmıştır.

Elde edilen veriler içerik ve tanım analizleri doğrultusunda öncelikle bölüm içinde analiz edilmiştir. Çalışmada daha sonra her bir yönetici için iki ayrı basamakta yapılan mülakatlar birleştirilerek içsel motivasyon düzeyleri ile politik taktik uygulamaları arasındaki ilişki kurulmaya çalışılmıştır. Bu aşamadaki karşılıklı ilişki kurmaya dair değerlendirmeler iki ayrı araştırmacı tarafından bağımsız bir şekilde ayrı ayrı yapılmış ve daha sonra karşılaştırılmıştır. Elde edilen sonuçların birbirini destekler nitelikte olduğu ortaya çıkmıştır. Bu değerlendirme tarzı ile iç geçerlilik çalışması da sağlanmıştır.

\section{Bulgular Ve Tartışma}

Araştırmanın birinci bölümünde içsel motivasyon düzeyini belirlemeye yönelik analizler yapılmıştır. Bu aşamada, katılımcıların mülakatta verdikleri cevaplar araştırmacılar tarafından diğer katılımcılar ile karşılaştırarak içerik ve tanım analizlerine tabi tutularak içsel motivasyonları $\ddot{u} c ̧$ temel sınıfa ayrılmıştır: içsel motivasyonları düşük, içsel motivasyonları orta ve içsel motivasyonları yüksek. İncelemeler sonucunda katılımcıların içsel düzeyleri aşağıdaki gibi değişkenlik göstermiştir.

Tablo 2. Yöneticilere İçsel Motivasyon Düzeyleri

\begin{tabular}{llll}
\hline & $\begin{array}{l}\text { DÜşÜK } \\
\text { MOTIVASYON }\end{array}$ & $\begin{array}{l}\text { ORTA } \\
\text { MOTIVASYON }\end{array}$ & $\begin{array}{l}\text { YÜKSEK } \\
\text { MOTIVASYON }\end{array}$ \\
\hline $\begin{array}{l}\text { Yetki ve } \\
\text { sorumluluklar }\end{array}$ & $\mathrm{n}=6$ & $\mathrm{n}=2$ & $\mathrm{n}=8$ \\
& $\begin{array}{l}\text { Az ve çalışma } \\
\text { şevkini kırmaktadır }\end{array}$ & $\begin{array}{l}\text { yeterli ve üst } \\
\text { yönetim tarafından } \\
\text { belirlenmekte }\end{array}$ & $\begin{array}{l}\text { fazla ve çalısma azmini } \\
\text { arttırmakta }\end{array}$ \\
\hline İş yoğunluğu & $\begin{array}{l}\mathrm{n}=14 \\
\text { Yoğun ve daha iyi iş }\end{array}$ & $\begin{array}{l}\mathrm{n}=2 \\
\text { fazla iş yapmakta ve } \\
\text { bunun bir katma değeri } \\
\text { olduğuna inanmakta }\end{array}$ \\
\hline
\end{tabular}




\begin{tabular}{|c|c|c|c|}
\hline Görev tanımları & $\begin{array}{l}\mathrm{n}=8 \\
\text { sikı sık1 } \\
\text { sarılmaktalar }\end{array}$ & - & $\begin{array}{l}\mathrm{n}=8 \\
\text { Dışına çıkmaktalar ve } \\
\text { kendilerini daha iyi his- } \\
\text { setmektedirler }\end{array}$ \\
\hline İş yetkinlik uyumu & $\begin{array}{l}\mathrm{n}=9 \\
\text { yönettikleri birim } \\
\text { ile yetki ve beceri- } \\
\text { leri uyumlu }\end{array}$ & - & $\begin{array}{l}\mathrm{n}=7 \\
\text { bulunduğu makamın } \\
\text { üstünü hak etmektedir- } \\
\text { ler ve daha çok yetkileri } \\
\text { olsa daha etkin işler ya- } \\
\text { pabilecekler }\end{array}$ \\
\hline Sayg1 & $\begin{array}{l}\mathrm{n}=4 \\
\text { üst yönetim, birim } \\
\text { ve makamlarına } \\
\text { saygı duymamakta, } \\
\text { atıl görmekte }\end{array}$ & $\begin{array}{l}\mathrm{n}=5 \\
\text { üst yönetim, birim ve } \\
\text { makamlarına sayg1 } \\
\text { duymakta, ancak yete- } \\
\text { rince ilgilenmemekte }\end{array}$ & $\begin{array}{l}\text { n=7 } \\
\text { üst yönetim, birim ve } \\
\text { makamlarına sayg1 } \\
\text { duymakta, ve daha } \\
\text { fazla çaba sarf etmeye } \\
\text { itmekte }\end{array}$ \\
\hline $\begin{array}{l}\text { Sorumlu } \\
\text { Olmak }\end{array}$ & $\begin{array}{l}\mathrm{n}=4 \\
\text { bulundukları ma- } \\
\text { kam sorumluluk } \\
\text { gerektirmeme bun- } \\
\text { dan şikayetçi değil- } \\
\text { ler }\end{array}$ & $\begin{array}{l}\mathrm{n}=8 \\
\text { sorumluluk alma üst } \\
\text { yönetimin inisiyati- } \\
\text { finde ve danışılmadan } \\
\text { sorumluluk alınamaz }\end{array}$ & $\begin{array}{l}\mathrm{n}=5 \\
\text { Çalışanları için her } \\
\text { türlü sorumluluk alabi- } \\
\text { lirler ve bu sayede çalı- } \\
\text { şanların saygısını kaza- } \\
\text { nırlar }\end{array}$ \\
\hline Pozisyon & $\begin{array}{l}\mathrm{n}=7 \\
\text { yönetimin kendile- } \\
\text { rini az önemli gör- } \\
\text { mekte (ya da bilme- } \\
\text { mekte) ancak etkin } \\
\text { çalışmaktalar }\end{array}$ & $\begin{array}{l}\mathrm{n}=3 \\
\text { Kilit pozisyonda ve di- } \\
\text { ğer yöneticilerden daha } \\
\text { zor bir iş yapmaktalar }\end{array}$ & $\begin{array}{l}\mathrm{n}=6 \\
\text { çalışan sayısı az ve esas } \\
\text { işlere destek birim ola- } \\
\text { rak çalışmaktalar }\end{array}$ \\
\hline Karar Alma & $\begin{array}{l}\mathrm{n}=5 \\
\text { Üst yönetime danış- } \\
\text { madan herhangi bir } \\
\text { karar almaz }\end{array}$ & $\begin{array}{l}\mathrm{n}=6 \\
\text { Kararlar üst yönetimle } \\
\text { ortak şekilde alınır }\end{array}$ & $\begin{array}{l}\mathrm{n}=5 \\
\text { Kendileri karar alır ve } \\
\text { üst yönetimin onayına } \\
\text { ihtiyaç yoktur }\end{array}$ \\
\hline İlişkiler & $\begin{array}{l}\mathrm{n}=3 \\
\text { Yönetimle araları } \\
\text { bozuk ve çalışan- } \\
\text { larla resmi ilişkiler }\end{array}$ & $\begin{array}{l}\mathrm{n}=11 \\
\text { ya yöneticisi ya da çalı- } \\
\text { şanları açısından sıra- } \\
\text { dan bir yönetici, }\end{array}$ & $\begin{array}{l}\mathrm{n}=2 \\
\text { üst yönetim tanıyor ve } \\
\text { çalışanlar seviyor, iliş- } \\
\text { kiler iyi }\end{array}$ \\
\hline Eğitim-İş ilişkisi & $\begin{array}{l}\mathrm{n}=10 \\
\text { aldıkları eğitim ile } \\
\text { yaptıkları iş uyum- } \\
\text { suz, yöneticilik aka- } \\
\text { demik eğitimden } \\
\text { farklı }\end{array}$ & - & $\begin{array}{l}\mathrm{n}=6 \\
\text { aldıkları eğitim ile yap- } \\
\text { tıkları iş uyumlu ve bi- } \\
\text { rimleri için bilimsel ça- } \\
\text { lışmalar uyguluyor }\end{array}$ \\
\hline
\end{tabular}

Araştırmanın ikinci bölümünde ise araştırmacı 6 temel politik taktik için yapı yapılandırılmış 12 adet ifadeye verdikleri cevaplar araştırmacılar tarafından incelenmiştir. Elde edilen cevaplar tanım ve içerik analizi açısından değerlendirilmiş ve her bir yöneticinin politik taktiklere başvurma 
düzeyleri 3 temel sınıf içerisinde ele alınmıştır: politik taktikleri çoğu zaman kullanır, politik taktikleri ara sıra kullanır, politik taktikleri hiç kullanmaz.

Genel olarak içsel motivasyonları yüksek olan yöneticilerin 6 temel politik taktik uygulaması hususunda çekingen davrandıkları görülmüştür. Özellikle içsel motivasyonu yüksek olan yöneticilerin 'göze girme', 'destek oluşturma' ve 'mübadele' taktiklerini hiç kullanmadıkları ve az sayıda 'üst makama başvurma' ve 'kendini fark ettirme' taktiğine başvurduğu görülmüştür. Bu tip yöneticilerin en fazla kullandığı taktik ise 'mantıkla ikna etme' olarak görülmüştür.

İçsel motivasyonları orta derece olan yöneticiler için ise durum biraz farklıdır. Bu yöneticiler sadece 'mantıkla ikna etme' taktiğini hiç kullanmayıp, özellikle 'mübadele' ve 'kendini fark ettirme' taktiklerini uygulamaktadirlar.

İçsel motivasyonları düşük olan yöneticiler ise; tüm politik taktikleri uygulamayı seçtikleri ve en fazla 'üst yönetime başvurma', 'göze girme' ve 'destek oluşturma' taktiklerini kullandıkları görülmüştür.

Göze Girme : katıllmcllara sorulan; 1) taleplerinizi bilimler verilere dayanarak mı yoksa hürmetkar davranarak mı belirtirsiniz?2) taleplerinizi üst yönetimin keyifli anında mi, dostça yaklaşarak mi, güç mesafesini koruyarak mı iletirsiniz?

- $\quad \mathrm{n}=11$ üst yönetim ile yapılan görüşmelerde hürmetkar ve aşırı saygilı davranarak taleplerini dile getirdiklerini belirtirken

- $\mathrm{n}=5$ katılımcı ise üst yönetime bilimsel veriler sunarak taleplerini dile getirmeye çalıştıklarını belirtmişlerdir.

- $\mathrm{n}=7$ katılımc üst yönetimden istekte bulunulacağı zamanı kollayıp onların keyifli oldukları anı yakalamaya çalıştığını belirtmiştir.

- $\mathrm{n}=4$ katılımc ise isteklerini dostane bir sohbet ortamında dile getirmeyi uygun bulmakta

- $\quad \mathrm{n}=5$ katılımcı ise güç mesafesinin önemli olduğunu ve isteklerini kendilerinin uygun olduğu zamanda dile getirdiklerini belirtmişlerdir. 
Destek Oluşturma : katılımcılara sorulan; 1)iş ile ilgili kararlarda astlarınızın desteğini ararmısınız? Üst yönetime yapılacak sunum ve bilgilendirmeler de çalışanlarınızın katkıların göstermelerini ister misiniz?2)Yönetsel konularda ve genel şirket politikalarında yapmayı düşündüğ̈̈̈üz değişikler için diğer birim yöneticileri ile istişare edip onların yardımın ister misiniz? Yoksa bu konularda üst yönetime şahsi başvuru mu yaparsınız?

- $\mathrm{n}=6$ üst yönetime yapılacak proje ve sunumlarda çalışanlarını kullandığını

- $\mathrm{n}=5$ proje ve sunumlarda çalışanların fikirlerini aldığını fakat kendi hazırladığını

- $\mathrm{n}=5$ çalışanları bu tür karıştırmadığını ifade etmişlerdir.

- $\mathrm{n}=9$ yönetsel konularda ve büyük değişiklik gerektiren kararların alınmasında ise katılımcıların diğer yöneticilerin desteğini istediğini ve onların desteğini arkasına alarak daha güçlü isteklerde bulunduğunu,

- $\mathrm{n}=4$ katılımcı ise bu tür önemli değişimlerde üst yönetim ile tek başına görüşmeyi tercih ettiğini belirtmiştir.

- $\mathrm{n}=3$ katılımcı ise projeler ve değişiklikler için diğer yöneticilerin desteğini arkama alır fakat görüşmeyi tek başıma yaparım demiştir.

Üst makama başvurma : katılımcılara sorulan; 1) Personel açığınız olduğunu düşünüyorsunuz ve eleman alımları başladı. Üst yönetimden birilerini araya koyarak talep ettiğiniz personelleri almaya çalışır mısınız? Yoksa herhangi bir talepte bulunmadan size verilen personelle yetinir misiniz? 2) Bir üst amiriniz ile dost/arkadaş olan kişileri arayıp bulur musunuz? Onlarla iyi ilişkiler geliştirmek için fırsat kollar mısınız? Yoksa amirinizle kurmay uzmanlığınız vasıtasıyla mı ilişki kurarsınız?

- $\mathrm{n}=7$ daha iyi nitelikli personel almak için üst yönetimden tanıdıklarına başvurabileceklerini belirtirken $n=6$ katılımcı üst yönetimden tanıdıkları araya sokarak isim vermeden personel sayısını artırabileceğini 
- $\mathrm{n}=3$ katılımcı ise kimseye minnet etmeden verilen sayıda personelle işleri yürütmeye çalışacağını belirtmiştir

- $\mathrm{n}=9$ katılımcı üst amirinin dostlarını gözlemlediğini ve fırsat bulursa onlarla tanışmaya çalıştığını belirtirken üst yönetimin istekleri ve yöneticilerin isteklerinin kesişmesi noktasında

- $\quad \mathrm{n}=7$ katılımcı ise üst amirine karşı güç mesafesinin fazla olduğunu belirtmiştir

Mübadele : katılımcılara sorulan; 1) Üst yönetimin sizden isteklerine karş1 ani ve net olarak kabul mu dersiniz? Üst yönetimin taleplerini kayıtsız olarak yerine getirir misiniz? Yoksa İstekler geldikçe aşırı yoğunluğu gösterip yavaştan mı alırsınız veya talepler karşılığında sizde isteklerde bulunur musunuz? 2) Yönettiğiniz birim için veya şahsi olarak üst yönetimden taleplerde bulunurken bunların gerçekleşmesi durumunda sizin üst yönetimi karşılıksız bırakmayacağınızı belli eder misiniz? Geçmiş iyiliklerinizi bolca hatırlatır misınız yoksa tavrınız daha ısrarcı mı olur?

- $\mathrm{n}=7$ katılımcı ise isteklerinin şirket için olduğunu ve ısrar ederek net cevap beklediklerini belirtmişlerdir

- $\mathrm{n}=8$ ise bu istekleri sinıflandırdıklarını ve hızlı yapmaları karşıllı̆ında bazı talepler de bulunduklarını belirtmişlerdir.

- $\mathrm{n}=8$ üst yönetimden gelen talepleri hızlı bir şekilde ve fazla sorgulamadan hayat geçiririm

- $\mathrm{n}=9$ yönetici üst amirine üstü kapalı işlerini halletmesi karş11ğında bazı tavizleri vereceğini belirtmiştir

Kendini fark ettirme : katılımcılara sorulan; 1) Üst yönetimle olan toplant1larda sürekli bilgi, beceri ve yeteneklerinizi anlatarak mı sunum yapars1nız yoksa biriminizdeki ilerlemenin çalışanlarınızın eseri olduğunu mu anlatırsınız? 2) Üst yönetimle görüşürken sorunlu ve çözülmesi gereken bir konuda deneyim ve bilginiz olmasa bile olduğunuzdan daha yeterli gözükerek işi alır mısınız? Yoksa işi sonuçlandıramayacağınızı düşünüp başkalarının almasını mı beklersiniz?

- $\mathrm{n}=13$ üst yönetime y1llık raporlarda veya sunumlarda kendi yetenek ve becerilerini anlatarak söze başladıklarını ve bunun etkili olduğunu belirtmişlerdir 
- $\mathrm{n}=3$ katılımcı ise rapor ve sunumlarda çalışanlarını övdüklerini belirtmişlerdir

- Uzmanı olmadıkları bir iş için bile üst yönetimin dikkatini çekmek için işi almaları hususunda ise $n=11$ katılımcı işi alacağını ve önemli olanın işin sonucu değil o anki cesaret olduğunu belirtmiş

- $\mathrm{n}=5$ katılımc ise uzmanlığı olmayan işlerden uzak duracaklarını belirtmişlerdir

Mantıkla ikna etme : katılımcılara sorulan; 1) Üst yönetim ile olan görüşmelerinize somut kanıtlar ve belgeler ile gider misiniz? Sürekli mantıksal sorular sorarak dikkatleri üzerinize çeker misiniz? Yoksa daha genel ve sohbet havasında bir görüşmemi tercih edersiniz? 2) Üst yönetimden gelen eleştirilere boğun eğer ve nasıl istersiniz mi dersiniz? Yoksa mantıklı sebepler ileri sürerek eleştirileri bertaraf edip başka yöne mi çekersiniz?

- $\mathrm{n}=4$ üst yönetimle görüşmelere somut verilerle gittiklerini

- $\mathrm{n}=5$ ise somut verilerin tehlikeli olduğunu

- $\mathrm{n}=7$ katılımcı ise üst yönetimle görüşmelerde daha sohbet havası olmasını tercih ettiklerini belirtmişlerdir

- Üst yönetimden gelen eleştiriler için ise katılımcılardan $n=8$ tercihen eleştirilere karşı çıkmayıp kabullendiklerini

- $\mathrm{n}=3$ ise eleştirileri haklı bulur gibi davranıp akabinde kendi bildiğine devam ettiklerini

- $\mathrm{n}=5$ katılımcı ise üst yönetimden gelen eleştirilere karşı bilimsel verilerle karşı çıkacaklarını belirtmişlerdir

Çalışmanın yönetim ve organizasyon literatürüne katkıları ise Tablo 3. incelendiğinde daha da detaylı olarak orta çıkacaktır. İçsel motivasyon ile yöneticilerin örgütte kullandıkları politik taktikler arasında belirgin bir ilişki gözlemlenmiştir. Özellikle yüksek iç motivasyona sahip yöneticilerin ciddi anlamda taktik uygulamaktan kaçındıkları ve kullanmak durumunda kaldıklarında ise mantıkla ikna seçeneğinde yoğunlaştıkları görülmektedir. Bu da örgüt düzeyinde incelendiğinde yöneticilerin içsel motivasyonlarını artırmaya yönelik çalışmalar yapılması, onların politik taktiklere başvurmadaki sıklıklarını azalabileceğini düşündürmektedir. 
Tablo 3. Yöneticilerin Politik Taktikleri Kullanma Sıklıkları ve İç Motivasyon Düzeyleri

\begin{tabular}{|c|c|}
\hline Araştırma Soruları & Bulgular \\
\hline $\begin{array}{l}\text { "acaba yöneticiler arasında içsel motivasyon dü- } \\
\text { zeyleri açısından politik taktik kullanımı farklılaş- } \\
\text { makta mıdır?" }\end{array}$ & $\begin{array}{l}\text { yöneticilerin içsel motivasyonları değişiklik } \\
\text { göstermekte ve bu farklılık düzeyi onların poli- } \\
\text { tik taktik kullanım şekillerini ve oranların } \\
\text { etkilemekte olduğu görülmüştür. }\end{array}$ \\
\hline $\begin{array}{l}\text { "yöneticiler içsel motivasyon düzeyleri düştükçe, } \\
\text { daha mı çok politik taktik kullanılmaktadır?" }\end{array}$ & $\begin{array}{l}\text { bu noktada elde edilen bulgular sorumuzu } \\
\text { destekler niteliktedir. İçsel motivasyonu düşük } \\
\text { ve/veya çok az olan yöneticiler sıklıkla politik } \\
\text { taktikleri kullanmakta ve kendilerince en etkili } \\
\text { olan taktikleri ise 'üst yönetime başvurma', 'göze } \\
\text { girme' ve 'destek oluşturma' olarak be- } \\
\text { lirtmişlerdir. Bu taktiklerin ortak noktaları ar- } \\
\text { andığında ise tamamında, "başka kişilerin al- } \\
\text { gılarında pozitif tutum oluşturma" hususu ortaya } \\
\text { çıkmaktadır. Bu da içsel motivasyonu yüksek } \\
\text { olan yöneticilerin başkalarının/üst yöneticinin } \\
\text { pozitif algısına ihtiyaç duymadığın } \\
\text { göstermektedir. }\end{array}$ \\
\hline $\begin{array}{l}\text { "sert ve yumuşak politik taktikler hangi içsel mo- } \\
\text { tivasyon düzeyinde daha belirgin olarak kullanıl- } \\
\text { maktadır?" }\end{array}$ & $\begin{array}{l}\text { yumuşak (göze girme, mantıkla ikna etme) ve } \\
\text { sert politik taktiklerin motivasyon düzeyleri } \\
\text { arasındaki dağllım incelendiğinde ise mantıklı } \\
\text { ve tutarlı bir dağılım görülmemektedir. Bura- } \\
\text { dan ise; her düzeydeki motivasyon unsuruna } \\
\text { sahip yöneticilerin bu taktikleri } \\
\text { olumlu/olumsuz şekilde algılamadıkları, poli- } \\
\text { tik taktikleri kendi motivasyon/iş/makam } \\
\text { açısından ele alıp uyguladıkları sonucuna } \\
\text { varılmıştır. }\end{array}$ \\
\hline
\end{tabular}

Düşük seviyede iç motivasyona sahip yöneticiler ise tüm politik taktikleri kullandıkları görülmekte olup, bu da yöneticilerin politik taktikler kullanmak suretiyle kendilerini işe ve makama daha layık görebildikleri ve/veya örgüt içindeki yerlerini sağlamlaştırmak içinde bu taktiklere başvurdukları varsayımlarını çıkarabilmekteyiz. Bu yöneticilerin iş algıları, makamlarının önemi ve profesyonel iş çalışması bilinçleri artırılabilir ise içsel motivasyonlarında artış ve politik taktiklere başvurma sıklıklarında ise azalışın sağlanabileceği düşünülmektedir. 


\section{Araştırmanın Kısıtları ve Öneriler}

Bu araştırmanın en önemli kısıtlarından biri örneklem sayısı olarak karşımıza çıkmaktadır. Buna karşın nitel araştırmalarda örneklem sayısının 15 'ten yüksek olması çalışmanın yeterliliğgi açısından uygun görülmektedir. Diğer bir kısıt ise; araştırma büyük ölçekli bir şirketin sadece bir bölümündeki yöneticiler üzerine uygulanmış olmasıdır. Bu nedenle alınan sonuçlar sadece spesifik bir bölüm için kabul edilecek olup işletme geneli için ise varsayımlarda bulunulabilecektir.

\section{Gelecekteki Çalışmalar İçin Öneriler}

- Bu çalışma sektör ayrımı yapılarak yöneticilerin hangi sektörlerde daha fazla politik taktiğe başvurdukları araştırılabilir.

- Çalışmadaki örneklem sayısı artırılarak yöneticiler perspektifinden nicel bir çalışma yapılabilir. 
EXTENDED ABSTRACT

\title{
Political Tactics: A Reflection Of Intrinsic Motiva- tion? A Research In The Aviation Industry From Managers Perspective
}

\author{
* \\ Taha Yusuf Çakarel - Deniz Börü - Bekir Alper Yıldırım \\ Istanbul Kültür University, Marmara University
}

Organizations are structures that operate to achieve specific goals or objectives. Organizations that provide the necessary resources to achieve these objectives endeavor to achieve maximum output with minimum input. The most important resource in the mentioned effort is the person who will perform the tasks and the willingness of those people. When the studies carried out are analyzed, the motivation that is defined as internal and external is the source of the effect that motivates and motivates people. Organizational structure and managers are the most important factors in ensuring the motivation of individuals. (Özadaşlı and Akman, 2012). The limited resources of organizations and the fact that individuals are competing with each other in the sharing of resources lead to the formation of political behaviors and the use of political tactics to each other (Robbins, 2001).

Intrinsic motivation can be defined as the experience of individuals to demonstrate their own abilities (Brief and Aldag, 1977). Intrinsic motivation can be achieved by any reward that appears outside the work of individuals in performing an activity (Deci, 1972). From this point of view, there is a fast and direct connection between work and reward in intrinsic motivation (Newstrom and Davis, 2002). In short, intrinsic motivation is the experience of showing the competence and skills of the individual (Y1lmaz, 2018).

Intentional behaviors aiming to provide benefits to the practitioner in the short and long term through the strategic use of behavior and political tactics as influencing tactics have been defined (İslamoğlu and Börü, 2007). 
Many researchers have linked the use of political tactics to personal interests and limited them (İslamoğlu and Börü, 2007; Drory and VigodaGadot, 2010; Dulebohn etc., 2005; Hochwarter etc., 2000; Parker, 1995). Steensma (2007) classified political tactics as six basic tactics; It is defined as engaging, creating support, applying to the upper authority, exchange, self-awareness and persuasion through logic.

In the literature, the use of political tactics in the work environment of employees is basically gathered under two factors; reasons of individual interaction and reasons of organizational-business interaction (Arikan, 2011). Treadway et al. (2005) showed that political tactics and political behaviors will be higher in people who have high success and high intrinsic motivation.

The general purpose of this study; The aim of this course is to examine the internal motivation levels of managers and the political tactics they use in the workplace and to reveal the relationship between intrinsic motivation levels and the frequency of applying political tactics. For this purpose, the sample of the research conducted in the domestic airline companies operating in Turkey and abroad constitute $\mathrm{n}=16$ administrator. Interviews were conducted with the administrators with semi-structured interview forms prepared by the researchers.

After the interviews, the internal motivations of the managers were categorized as low, medium and high and evaluations were made according to these criteria.

As a result of the study, it was observed that there is a significant relationship between intrinsic motivation and the political tactics used by managers within the organization. It is seen that managers with a high level of intrinsic motivation avoid using political tactics, and when they have to do so, they choose the method of persuasion with logic. It was found that managers with low intrinsic motivation used all political tactics.

\section{Kaynakça / References}

Adem, Ö., Akgemci, T. ve Demirsel, M. T. (2004). Stratejik insan kaynakları yönetimi bağlamında örgütlerde işgören motivasyonu süreci. Selçuk Üniversitesi Sosyal Bilimler Enstitüsü Dergisi, 12, 277-290. 
Amabile, T. M., Hill, K. G., Hennesey, B. A. ve Tighe, E. M. (1994). The preference inventory: Assessing intrinsic and extrinsic motivational orientations, Journal of Personality and Social Psychology, 66(5), 393-399.

Appelbaum, S. H. Ve Hughes, B. (1998). Ingratiation as a political tactic: Effects within the organization. Management Decision, 36(2), 85-95.

Arıkan, S. (2011). İşyerinde kullanılan politik taktiklere yönelik olası bireysel önceller üzerine bir araştırma. Türk Psikoloji Dergisi, 26(68), 52-71.

Armağan, A. (2005). Örgütsel politik davranışın analizi: İzmir yazılı bas1nunda bir uygulama. Yönetim ve Ekonomi Araştırmaları Dergisi, 3(4), 91-107.

Bağcı Z. ve Bursalı Y.M. (2011). Yöneticilerin güç algılarının çalışanların örgüte bağlılıkları üzerine etkisi: Çalışanların algılarına bağımlı analitik bir inceleme. Pamukkale Üniversitesi Sosyal Bilimler Enstitüsü Dergisi, 9, 9-21.

Batmaz N. Y. ve Gürer. A. (2016). Dönüştürücü liderliğin çalışanların içsel motivasyonu üzerindeki etkisi: Yerel yönetimlerde karşılaştırmalı bir araştırma. Süleyman Demirel Üniversitesi İktisadi İdari Bilimler Fakültesi Dergisi, 21(2), 477-492.

Boddewyn, J. J. ve Brewer, T. L. (1994). International-business political behavior: New theoretical directions. Academy of Management Review, 19(1), 119-143.

Brief, A. P. ve Aldag, R. J. (1977). The intrinsic-extrinsic dichotomy: toward conceptual clarity. Academy of Management Review, 2(3), 496-500.

Bruins, J. (1999). Social power and influence tactics: A theoretical introduction. Journal Of Social İssues, 55(1), 7-14.

Ceylan, C. (2004). Mentorluk ilişkilerine farklı bir yaklaşım: Kariyere uyarlı mentorluk. Isguc The Journal of Industrial Relations And Human Resources, 6(1), 0-0.

Çalışkan, K. (2006). Political behavior in organizations: Antecendents and consequences. Doktora Tezi, Marmara Üniversitesi Sosyal Bilimler Enstitüsü.

Deci, E. L. (1972). Intrinsic motivation, extrinsic reinforcement, and inequity. Journal of Personality And Social Psychology, 22(1), 113-120. 
Drory, A. ve Vigoda-Gadot, E. (2010). Organizational politics and human resource management: A typology and the Israeli experience. $\mathrm{Hu}$ man Resource Management Review, 20(3), 194-202.

Dulebohn, J. H., Shore, L. M., Kunze, M., ve Dookeran, D. (2005). The differential impact of ocbs and influence tactics on leader reward behavior and performance ratings over time. Organizational Analysis (15517470), 13(1), 73-91.

Dündar, S., Özutku, H., ve Taşpınar, F. (2007). İçsel ve dışsal motivasyon araçlarının işgörenlerin motivasyonu üzerindeki etkisi: Ampirik bir inceleme. Ticaret Ve Turizm Eğitim Fakültesi Dergisi, 2, 105-119.

Elias, B., O'neil, J. ve Sanderson, D. (2004). The politics of trust and participation: A case study in developing first nations and university capacity to build health information systems in a first nations context. International Journal of Indigenous Health, 1(1), 68-78.

Emre, O. R. U. Ç., ve Kutanis, R. Ö. (YIL). Pozitif psikolojik sermayenin örgüt içi politik davranışlara etkisi: Akademisyenler üzerine bir araştırma. İşletme Araştırmaları Dergisi, 3(7), 36-58.

Ergül, H. F. (2005). Motivasyon ve motivasyon teknikleri. Elektronik Sosyal Bilimler Dergisi, 4(14), 67-79.

Eryılmaz, İ. ve Gülova, A. A. (2017). Örgüt ikliminin, algılanan örgütsel politika üzerine etkisi: Kamu sektöründe bir araştırma. Mcbü Sosyal Bilimler Dergisi, 15(4), 155-176.

Gürkan, G. Ç. ve Demiralay T. (2017). Bireysel yenilikçiliğin çalışanın yenilikçi davranışı üzerindeki etkisinde içsel motivasyonun aracılık rolü: Türkiye'de cerrahlar örneği. Girişimcilik Ve İnovasyon Yönetimi Dergisi, 6, 65-81.

Hochwarter, W. A., Witt, L. A., ve Kacmar, K. M. (2000). Perceptions of organizational politics as a moderator of the relationship between consciousness and job performance. Journal Of Applied Psycho$\log y, 85(3), 472-478$.

İslamoğlu, G. ve Börü, D. (2007). Politik davranış boyutları: bir ölçek geliştirme çalışması. Akdeniz Üniversitesi İktisadi Ve İdari Bilimler Fakültesi Dergisi, 7(14), 135-153.

Judge, T. A., ve Bretz Jr, R. D. (1994). Political influence behavior and career success. Journal of Management, 20(1), 43-65. 
Kipnis, D., Schmidt, S. M., ve Wilkinson, I. (1980). Intraorganizational influence tactics: Explorations in getting one's way. Journal Of Applied Psychology, 65(4), 440-452.

Koçel, T. (2007). İşletme yöneticiliği. İstanbul:Arıkan Basım Yayın.

Liden, R. C., ve Mitchell, T. R. (1988). Ingratiatory behaviors in organizational settings. Academy Of Management Review, 13(4), 572-587.

Lipset, S. M. (1959). Political man: The Social Bases Of Politics.

Mohan-Bursalı, Y. (2008). Örgütsel politikanın işleyişi: Örgütsel politika algısı ve politik davranış arasındaki ilişkiler Doctoral Dissertation, Deü Sosyal Bilimleri Enstitüsü, İzmir.

Mottaz, C. J. (1985). The relative importance of intrinsic and extrinsic rewards as determinants of work satisfaction. The Sociological Quarterly, 26(3), 365-385.

Newstrom, J. W., ve Davis, K. (2002). Organizational behavior. (1st Ed.). New York: Mcgrawhill Higher Education.

Orpen, C. (1996). The effects of ingratiation and self-promotion tactics on employee career success. Social Behavior And Personality: An International Journal, 24(3), 213-214.

Özadaşlı, K., ve Akman, H. (2012). İçsel ve dışsal motivasyonda cinsiyet ve örgütsel statü farklılaşması: Türk Telekomünikasyon Aş çalışanları üzerinde bir araştırma. Süleyman Demirel Üniversitesi Vizyoner Dergisi, 4(7), 73-81.

Pandey, K. C. (1981). Kc Pandey, Phys. Rev. Lett. 47, 1913 (1981). Phys. Rev. Lett., 47, 1913.

Parker, P. M. (1995). Climatic effects on individual, social, and economic behavior: A physioeconomic review of research across disciplines. Westport, Ct: Greenwood Press.

Ralston, D. A. (1985). Employee ingratiation: The role of management. Academy Of Management Review, 10(3), 477-487.

Robbins, S. P. (2001). Organisational behaviour: Global and Southern African perspectives. South Africa:Pearson

Robbins, S.P., Judge, T.A. (2013). Örgütsel davranış. (İnci Erdem Çev. Ed.), İstanbul:Nobel Yay.

Ryan, R. M., ve Deci, E. L. (2000). Intrinsic and extrinsic motivations: Classic definitions and new directions. Contemporary Educational Psychology, 25(1), 54-67. 
Shankar, R. (1994). R. Shankar, Rev. Mod. Phys. 66, 129 (1994). Rev. Mod. Phys., 66, 129.

Steensma, H. (2007). Why managers prefer some infl uence tactics to other tactics: A net utility explanation. Journal Of Occupational And Organizational Psychology, 80, 355- 362.

Treadway, D. C., Hochwarter, W. A., Kacmar, C. J. ve Ferris, G. R. (2005). Political will, political skill, and political behavior. Journal Of Organizational Behavior: The International Journal Of Industrial, Occupational And Organizational Psychology And Behavior, 26(3), 229-245.

Türk, S., Aydoğan, E., ve Kansu, N. (2003). İçsel motivasyonun iş tatmini üzerindeki etkisi: Türk Tarih Kurumu matbaası Ve Nurol Matbaası'nda yapılan bir araştırma, 1. Matbaa Teknolojileri Sempozyumu, Eylül, Ankara. 21 Eylül 2007 tarihinde http://W3.gazi.edu.tr/Web/Msturk/Yayinlar/Pdf/Motive.Pdf adresinden erişilmiştir.

Ülkeryıldız, R. E. (2009). Political tactics in building construction industry from the architects perspectives. Master's Thesis, Institute Of Technology, İzmir.

Veysel, A. Ğ. C. A. ve Ertan, H. (2008). Duygusal bağlılık içsel motivasyon ilişkisi: Antalya'da beş yıldızlı otellerde bir inceleme. Afyon Kocatepe Üniversitesi İktisadi Ve İdari Bilimler Fakültesi Dergisi, 10(2), 135156.

Woodworth, R. S. (1918). Dynamic psychology. Columbia University Press, Columbia.

Yaylacı, G. Ö. (2006). Kariyer yaşamında duygusal zeka ve iletişim yeteneği: Diyalog ve duyguları yönetmek. İstanbul:Hayat Yayıncılık.

Yılmaz, R. (2018). Psikolojik iklimin örgütsel vatandaşlı davranışı üzerindeki etkisinde içsel motivasyonun aracı rolü: Sanayi işletmelerinde bir araştırma, Doktora Tezi, Selçuk Üniversitesi İşletme Bilim Dalı, Konya.

Yukl, G. ve Falbe, C. M. (1990). Influence tactics and objectives in upward, downward, and lateral influence attempts. Journal Of Applied Psychology, 75(2), 132-140.

Yukl, G., ve Tracey, J. B. (1992). Consequences of influence tactics used with subordinates, peers, and the boss. Journal Of Applied Psycho$\log y, 77(4), 525-535$.

Zuckerman, A. S. (2005). The social logic of politics: Personal networks as contexts for political behavior. Philadelphia:Temple University Press. 


\section{Ek.1 Mülakat Soruları \\ İçsel Motivasyon Mülakat Soruları:}

1- Genel anlamda yönettiğiniz birimdeki yetkileriniz nelerdir? İşinizi tam olarak yapacak yetki ve güce sahip olduğunuzu düşünüyor musunuz? Bu düşünceniz sizi ne yönde etkiliyor?

2- İşinizin yoğun ve yorucu olduğunu düşünüyor musunuz? İşinizi gereği kadar mı yaparsınız yoksa işle ilgili başarılı olmak ve işinizi daha iyi yapmak sizi olumlu yönde etkiler mi?

3- İş tanımınız nelerdir? İşinizin görev tanımı dışına çıkar mısınız? İşiniz de görev tanımı dışındaki hususlarla ilgilenmek sizce şirketinize katma değer katar mı?

4- Şuan bulunduğunuz konum itibarı ile yönettiğiniz birim sizin yetenek ve becerilerinizi sergilemek için uygun bir makam mıdır?

5- Bulunduğunuz mevkii ve makama olan saygı ve ilgi sizce yeterince etkili mi? Üst yönetim tarafından etkili bir makam olarak görülüyor mu?

6- Bulunduğunuz birimde iş süreçlerini ve çalışanlarınızı göz önüne aldığınız da, işinizin gereği olarak sıkça sorumluluk alır mısınız?

7- Yönettiğiniz birimin şirket içinde önemli kilit bir pozisyon oynadığına inanıyor musunuz? Biriminiz destek birimi mi yoksa süreç birimi mi?

8- Yönettiğiniz birimde aldığınız kararları üst yönetimden bağımsız şekilde uyguluyor musunuz? Aldığınız kararların onaylanması önemli mi?

9- Yönettiğiniz birim bazında düşünerek, üst yönetim sizi ve biriminizi değerli bir şahıs olarak görüyor mu? Siz kendinizi yönettiğiniz birim bazında ve çalışanlar gözünde önemli bir kişilik olarak görüyor musunuz?

10- Almış olduğunuz eğitim nedir? Akademik eğitiminiz nedir? Bu aldığınız akademik eğitim ve bilgileri yönettiğiniz birimde kolaylıkla uygulayabiliyor musunuz? Bu imkana sahip misiniz 


\section{Politik Taktikler Mülakat Soruları:}

\section{Göze Girme:}

1- Üst yönetim ile yapılan görüşmelerde taleplerinizi şiddetli ve bilimsel tespitlere dayandırarak mı belirtirsiniz yoksa hürmetkar davranıp biriminizin zor durumda olduğunu belirterek mi?

2- Kişisel veya yönettiğiniz birim için yapacağınız bir talep/isteği üst yöneticinizin keyifli bir anına denk getirmek için çaba sarf eder misiniz? Üst yöneticinize dostça mı yaklaşırsınız yoksa güç mesafesini koruyarak mi?

\section{Destek Oluşturma:}

1- İşle ilgili bazı kararları alırken altınızda çalışan bireylerden olumlu destekler arar mısınız? Üst yönetime yapılacak sunum ve bilgilendirmeler de çalışanlarınızın katkılarını göstermelerini ister misiniz?

2- Yönetsel konularda ve genel şirket politikalarında yapmayı düşündüğünüz değişikler için diğer birim yöneticileri ile istişare edip onların yardımını ister misiniz? Yoksa bu konularda üst yönetime sahşi başvuru mu yaparsınız?

\section{Üst Makama Başvurma:}

1- Personel açı̆̆ınız olduğunu düşünüyorsunuz ve eleman alımları başladı. Üst yönetimden birilerini araya koyarak talep ettiğiniz personelleri almaya çalışır mısınız? Yoksa herhangi bir talepte bulunmadan size verilen personelle yetinir misiniz?

2- Bir üst amiriniz ile dost/arkadaş olan kişileri arayıp bulur musunuz? Onlarla iyi ilişkiler geliştirmek için fırsat kollar mısınız? Yoksa amirinizle kurmay uzmanlığınız vasıtasıyla mı ilişki kurarsiniz?

\section{Mübadele:}

1- Üst yönetimin sizden isteklerine karşı ani ve net olarak kabul mu dersiniz? Üst yönetimin taleplerini kayıtsız olarak yerine getirir misiniz? Yoksa İstekler geldikçe aşırı yoğunluğu gösterip 
yavaştan mı alırsınız veya talepler karşılığında sizde isteklerde bulunur musunuz?

2- Yönettiğiniz birim için veya şahsi olarak üst yönetimden taleplerde bulunurken bunların gerçekleşmesi durumunda sizin üst yönetimi karşılıksız bırakmayacağınızı belli eder misiniz? Geçmiş iyiliklerinizi bolca hatırlatır mısınız yoksa tavrınız daha 1 srarcı mı olur?

\section{Kendini Farkettirme:}

1- Üst yönetimle olan toplantılarda sürekli bilgi, beceri ve yeteneklerinizi anlatarak mi sunum yaparsınız yoksa biriminizdeki ilerlemenin çalışanlarınızın eseri olduğunu mu anlatırsinız?

2-Üst yönetimle görüşürken sorunlu ve çözülmesi gereken bir konuda deneyim ve bilginiz olmasa bile olduğunuzdan daha yeterli gözükerek işi alır mısınız? Yoksa işi sonuçlandıramayacağınızı düşünüp başkalarının almasını mı beklersiniz?

\section{Mantıkla İkna:}

1- Üst yönetim ile olan görüşmelerinize somut kanıtlar ve belgeler ile gider misiniz? Sürekli mantıksal sorular sorarak dikkatleri üzerinize çeker misiniz? Yoksa daha genel ve sohbet havasında bir görüşmemi tercih edersiniz?

2- Üst yönetimden gelen eleştirilere boğun eğer ve nasıl istersiniz mi dersiniz? Yoksa mantıklı sebepler ileri sürerek eleştirileri bertaraf edip başka yöne mi çekersiniz?

\section{Soruların Uyarlandığı İçsel Motivasyon Ölçeği (Dündar vd., 2007)}

- İM1-İsimi tam olarak yapabilecek yetki ve güce sahip olmak

- İM2-İsimi iyi yapmak ve işimde başarılı olmak

- İM3-İşimi gerektiğinde genişleterek şirketime katma değer

- katabilmek

- İM4-Yaptığım isin kişisel yetenek ve becerilerime uygun olması

- İM5-Yaptığım işin saygın bir iş olduğuna inanmak

- İM6-Yaptığım isle ilgili sorumluluk sahibi olmak

- IM7-Yaptığım isin önemli bir is olduğuna inanmak 
- İM8-Mesleğimin gereklerini bağımsız bir şekilde yerine getirebilmek

- İM9-Mesleğimle ilgili konularda müşterilerimin sorunlarına çözüm üretebilmek

- İM10-Kendimi önemli bir şahsiyet olarak gördüğüm bir is ortamina sahip olmak

- İM11-Almış olduğum eğitim sonucu edindiğim bilgileri uygulayabilme imkanımın olması

\section{Soruların Uyarlandığı Politik Taktikler Ölçeği ${ }^{1}$}

- Bir şeyi yapması karşılığı yardım etmek

- Karşılık alarak iltimas geçmek

- İstediğimi yapması neticesinde onun için özveride bulunacağımı belirtmek

- Bir şey isterken geçmişte yaptığım iyilikleri hatırlatmak

- Benim için yaptığı iyiliğin karşılıksız kalmayacağı mesajını vermek

- Amirin ilgisini çekmek için olduğundan bilgili gözükmek

- Bilgi, beceri ve yeteneklerini abartmak

- Başarılı gözükerek ilgiyi üzerine çekmek

- Olduğumdan daha yeterli gözükerek isteğimi kabul ettirmek

- Amirime kendisini önemli hissettirmek

- İkna edici kanitlar göstermek

- Mantıklı nedenler ileri sürmek

- Açık açık talepte bulunmak

- Sorular sorarak kontrol etmek

- Bir şey isterken hürmetkâr davranma

- Hakkımda olumlu düşünmesini sağlama

- İsteklerini amirimin keyifli zamanına denk getirme

- Dostça yaklaşma

- Amire övgüde bulunma

- Üst yönetimden birilerini ayarlayarak istediklerini yaptırmak

- Üst yönetim ile resmi yollardan bağlantıya geçerek amiri etkilemek 
- Amir üzerinde etkili olabilecek kişiler ile ilişkileri geliştirmek

- İşarkadaşlarının desteğini sağlama

- Altında çalışanlardan destek alma

- Şirkette çalışan diğer kişilerden yardım isteme

\section{Kaynakça Bilgisi / Citation Information}

Çakarel, Y. T., Elber-Börü, D. ve Yıldırım, B. A. (2019 Politik taktikler: İçsel motivasyonun bir yansıması mı? yöneticiler perspektifinden havacılık sektöründe bir araştırma. OPUS-Uluslararası Toplum Araştırmaları Dergisi , 12(18. UíK Özel Sayısı), 138-166. DOI: 10.26466/opus.585532. 